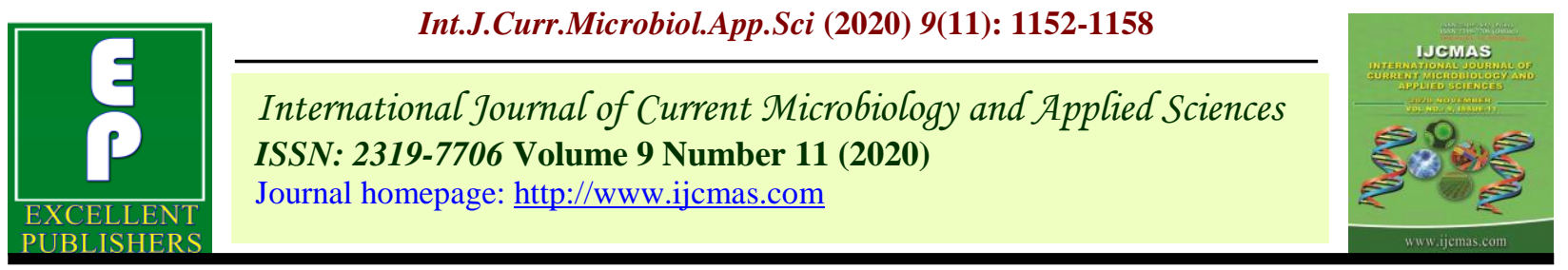

Original Research Article

https://doi.org/10.20546/ijcmas.2020.911.134

\title{
Ante-partum Body Condition Score and Non-genetic Factors Influencing the Post-partum Fertility in Murrah Buffaloes
}

\author{
Cherryl D. Miranda ${ }^{*}$, A. K. S. Tomar, Gyanendra Singh, \\ Hari Om Pandey, Pratik R. Wankhede and Arun Somagond
}

Livestock Production and Management, ICAR-Indian Veterinary Research Institute (IVRI), Izatnagar, Bareilly, Uttar Pradesh, India

*Corresponding author

\section{A B S T R A C T}

\begin{tabular}{|l|}
\hline Ke y w o r d s \\
Body condition \\
score, Pre-partum, \\
Post-partum, \\
reproductive traits \\
\hline Article Info \\
$\begin{array}{l}\text { Accepted: } \\
10 \text { October } 2020 \\
\text { Available Online: } \\
10 \text { November } 2020\end{array}$ \\
\hline
\end{tabular}

Keywords

Body condition

Post-partum,

reproductive traits

tropics

\section{Introduction}

India is the first country in the world for number of buffaloes, with a population of 109.85 million contributing around $20.45 \%$ to the total livestock population in India and accounting for about $49 \%$ of total milk production in the country (BAHS 2019). Much higher production average in Indigenous buffalo $(6.19 \mathrm{~kg} /$ day/animal $)$ than that of indigenous cattle $(3.73 \mathrm{~kg} /$ day/animal $)$ with its unique feed conversion efficiency and adaptation expresses its importance as dairy animal in the country (BAHS 2019). Additionally, buffaloes contribute significantly towards meat production, draft power, manure production and fuel. Murrah is one of the superior breeds of Indian buffaloes and are found nationwide due to their higher milk production potential coupled with adaptation to wide environmental conditions and feed conversion efficiency. Major problems of buffalo production in India include environmental stress, low animal genetic potential, questionable breeding policies, insufficient nutrient supply and 
insufficient land holding for green fodder cultivation. In addition to these, high calf mortality, occurrence of diseases, delayed maturity in heifers, prevalence of nondescriptive breeds with low milk productivity and low price remuneration for milk have been threats for buffalo rearing in India (Tiwari et al., 2007; Sastry, 2003). Practices of feeding, breeding, health and housing management have a great influence on buffalo performance and ultimately influence dairy farmers' economy. Among all, reproductive performance is of major concern which possibly determines all other components of income generation in any organized dairy farm. Low reproductive performance in general and, in particular, in buffaloes, remains a major global economic problem, with a higher incidence in India (Ingawale and Dhoble, 2004). Scanty information is known about the non-genetic factors which may influence the postpartum reproductive performance in Murrah buffaloes. Hence, this study aimed to examine the non-genetic determinants influencing few postpartum reproductive parameters of Murrah buffaloes considering their body condition, which could help to adopt suitable evaluation procedures for improving cyclical reproductive economic characteristics of this breed and bring about certain alterations in management with respect to the factors especially in tropical conditions.

\section{Materials and Methods}

The present study on Murrah buffaloes was conducted at Cattle and Buffalo Farm (Livestock Production and Management Section), ICAR-Indian Veterinary Research Institute, Izatnagar (Bareilly), Uttar Pradesh, India. Under the study 68 advance pregnant Murrah buffaloes were considered as per the availability from February 2019 to December 2019 and post calving reproductive data was recorded upto April 2020. The animals had been well protected against adverse weather conditions. The buffaloes were housed in sheds provided with open paddocks. The separate open paddocks with shed under loose housing system were provided for dry, lactating and advanced pregnant buffaloes. Two months before the expected calving date, pregnant buffaloes were transferred to a single calving pen with ample space, proper ventilation and drainage facilities, feeding and watering facilities.

The nutritional requirement was met through balanced combination of green and dry fodders along with concentrate mixture supplementation. Reproductive data pertaining to post partum interval to estrus (PPIE), service period (SP), number of services per conception (NoS/C) and breeding efficiency (BE) were recorded. The conception rate $(\mathrm{CR})$ was estimated by the percentage of experimental buffaloes conceived out of the total buffaloes at different time interval ( $\leq 90$ days, 91-120 days, $\geq 120$ days) during the post partum period.

The reproductive data were grouped as per the different classes and analysed to examine the effects of pre-partum body condition score, lactation order (LO), age at calving, season of calving, body weight at calving and dry period on various reproductive traits. Data were grouped into 1(1LO), 2 (2-3LO) and 3 (>3) lactation order classes (LOC) and 1 ( $\leq 1095), 2$ (1096-1460), 3 (1461-1825) and 4 (>1825) age at calving classes (ACC). Season of calving was divided into winter (December to February), spring (March-April), summer (May-June), rainy (July to September) and autumn (October-November) classes and accordingly data were classified. The data was grouped into 1 ( $\leq 550 \mathrm{kgs}), 2(551-650 \mathrm{kgs})$, 3 (651-750kgs), 4(>750kgs) body weight at calving classes (BWCC) and 1(<90days), 2(91-120 days), 3(121-150days) and 
4(>150days) dry period classes (DPC). Data were subjected to IBM SPSS statistics 22.0 software package for analysis. The effect of non-genetic factors on reproductive parameters under study was ascertained through following fixed model

Yijklmno $=\mu+\mathrm{BCSi}+\mathrm{LOj}+\mathrm{ACCk}+\mathrm{SOCl}$

$+\mathrm{BWCm}++\mathrm{DPn}+$ eijklmno

Where Yijklmno = Observation of oth animal, $\mu=$ Overall mean, BCSi $=$ Fixed effect of ith $\mathrm{BCS}, \mathrm{LOj}=$ Fixed effect of jth $\mathrm{LO}, \mathrm{ACCk}=$ Fixed effect of kth ACC, $\mathrm{SOCl}=$ Fixed effect of lth SOC, BWCm = Fixed effect of mth BWC, DPn $=$ Fixed effect of nth DP, eijklmno $=$ Random error associated with Yijklmno.

All the experiment procedures were duly approved by the Institute Animal Ethics Committee of ICAR-Indian Veterinary Research Institute.

\section{Results and Discussion}

Table 1 describes post-partum estrus, conception and Rate of conception in Murrah buffaloes. Among the sixty eight buffaloes calved during the entire study period, only fifty three buffaloes exhibited post partum estrus and conception was recorded in thirty three buffaloes. Overall the conception rate was estimated to be 62.26 per cent during that period of study (Table 1). It was also studied that conception rate was very low upto 90 days post partum period and gradually increased. Similar work was published by Mouffolk et al., (2011) (Table 2)

\section{Effect of pre-partum body condition score}

It was observed during the post partum period that fewer services per conception (NoS/C), early SP and PPIE were achieved in buffaloes having $\leq 3.5$ pre-partum BCS. The overall mean value of NoS/C was similar to the findings of Boopathi et al., (2019). However non-significant differences existed between classes among the parameters and the results were in agreement with Jilek et al., (2008) who inferred that BCS recorded after calving has effect on reproductive indicators but not pre-partum BCS. Stefanska et al., (2016) and Godara et al., (2017) also found that BCS at calving did not significantly affect the reproductive parameters.

Bayram et al., (2012) has found significant effect of BCS at calving on reproductive parameters and reported service period of cows with $<3.0 \mathrm{BCS}$ at calving was longer and also services per conception was lower than in cows with higher BCS at calving. This indicates the body condition of the animal at calving highly influences the parameters under study. Kumar et al., (2018) reported that Frieswal cows with >3.5 BCS exhibited higher service period because of higher fat deposition that reduces the reproductive efficiency.

\section{Effect of Lactation Order}

It was observed that LO did not show significant effect on reproductive traits of buffaloes under study and the present result was in conformity with the reports of Zadeh and Akbarian (2015). However service period and PPIE was lower for buffaloes belonging to second and third lactation. Buffaloes in their first LO had the longest PPIE which decreased as the buffaloes got older. Messine et al., (2007) reported that young animals tend to have the longest open days, as the conditions are sub-optimal for fertility.

Therefore primiparous animals are more at risk of not conceiving than multiparous. Similarly Ramadan et al., (2018) also did not find any significant effect of parity/lactation order on PPIE of Egyptian buffaloes, while 
significant effect was observed on NoS/c and reported that NoS/C was lower as the parity increased (8th parity). Jamuna et al., (2015) found lower service period and days to first service in second and third parity in Murrah buffaloes which was similar in the present study. The mean service period and number of services per conception in first lactation buffaloes were found to be 153.64 days and 1.29 , respectively which was similar to Patil et al., (2012).

\section{Effect of age at calving}

Service period and breeding efficiency of buffaloes were significantly influenced by age at calving in the present study. Service period was found to be shorter in buffaloes with age at calving $\leq 1095$ days and also BE was found to be highest in the same class of buffaloes. Literature regarding effect of age at calving on reproductive parameters in buffaloes was not available.

Table.1 Reproductive parameters during post-partum days

\begin{tabular}{|c|c|c|c|}
\hline Post Partum Days & $\begin{array}{c}\text { \% of buffaloes exhibiting } \\
\text { postpartum estrus }\end{array}$ & $\begin{array}{c}\text { \% of buffaloes } \\
\text { conceived }\end{array}$ & CR \% \\
\hline S90d & $30.88(21)$ & $13.24(9)$ & 42.86 \\
\hline $\mathbf{9 1 - 1 2 0 ~ d ~}$ & $14.71(10)$ & $10.29(7)$ & 70.00 \\
\hline $\mathbf{2 1 2 1}$ d & $32.35(22)$ & $25.00(17)$ & 77.27 \\
\hline Overall & $77.94(53)$ & $48.52(33)$ & 62.26 \\
\hline
\end{tabular}

CR: Conception rate

Table.2 Factors influencing reproductive traits in Murrah buffaloes

\begin{tabular}{|c|c|c|c|c|c|}
\hline Particulars & NoS/C & SP (days) & PPIE (days) & BE $(\%)$ & $\operatorname{CR}(\%)$ \\
\hline \multirow[t]{2}{*}{ Overall mean } & $1.48 \pm 0.12$ & $145.73 \pm 13.64$ & $125.64 \pm 9.65$ & $84.45 \pm 1.81$ & \multirow[t]{2}{*}{62.26} \\
\hline & (33) & (33) & $(53)$ & $(47)$ & \\
\hline Pre-calving BCS & NS & NS & NS & NS & \\
\hline \multirow[t]{2}{*}{$1(\leq 3.5)$} & $1.43 \pm 0.13$ & $145.1 \pm 17.98$ & $121.09 \pm 11.16$ & $83.46 \pm 2.15$ & \multirow[t]{2}{*}{61.76} \\
\hline & $(21)$ & (21) & $(34)$ & (31) & \\
\hline \multirow[t]{2}{*}{$2(>3.5)$} & $1.58 \pm 0.26$ & $146.83 \pm 21.43$ & $133.79 \pm 18.32$ & $86.37 \pm 3.34$ & \multirow[t]{2}{*}{63.11} \\
\hline & (12) & (12) & (19) & (16) & \\
\hline Lactation Order & NS & NS & NS & NS & \\
\hline \multirow[t]{2}{*}{$1 \mathrm{LO}$} & $1.29 \pm 0.12$ & $153.64 \pm 21.39$ & $153.76 \pm 20.69$ & \multirow[t]{2}{*}{-} & \multirow[t]{2}{*}{82.35} \\
\hline & (14) & (14) & (17) & & \\
\hline \multirow[t]{2}{*}{ 2-3LO } & $1.56 \pm 0.24$ & $128.78 \pm 17.64$ & $100.57 \pm 11.43$ & $81.87 \pm 2.80$ & \multirow[t]{2}{*}{64.29} \\
\hline & (9) & (9) & (14) & (20) & \\
\hline \multirow[t]{2}{*}{$>3 \mathrm{LO}$} & $1.7 \pm 0.3$ & $149.9 \pm 31.13$ & $119.86 \pm 14.22$ & $86.36 \pm 2.34$ & \multirow[t]{2}{*}{45.45} \\
\hline & (10) & (10) & $(22)$ & $(27)$ & \\
\hline Age at Calving & NS & $*$ & NS & $* *$ & \multirow{3}{*}{50.00} \\
\hline \multirow[t]{2}{*}{1 ( $\leq 1095$ days $)$} & $1.12 \pm 0.12$ & $120.75 \pm 24.3$ & $117.44 \pm 12.44$ & $95.16 \pm 2.65$ & \\
\hline & (8) & (8) & (16) & (11) & \\
\hline \multirow[t]{2}{*}{ 2(1096-1460days) } & $1.62 \pm 0.17$ & $152.1 \pm 17.71$ & $129.97 \pm 15.16$ & $85.33 \pm 1.64$ & \multirow[t]{2}{*}{68.97} \\
\hline & (20) & (20) & (29) & $(28)$ & \\
\hline 3(1461-1825days) & $1.33 \pm 0.33$ & $155.67 \pm 63.65$ & $137.6 \pm 37.35$ & $69.89 \pm 2.36$ & 60.00 \\
\hline
\end{tabular}




\begin{tabular}{|c|c|c|c|c|c|}
\hline & (3) & (3) & (5) & (6) & \\
\hline \multirow[t]{2}{*}{ 4(>1825days) } & 2 & $182.0 \pm 19.62$ & $107.67 \pm 16.48$ & $56.85 \pm 3.51$ & \multirow{2}{*}{66.67} \\
\hline & (2) & (2) & (3) & (2) & \\
\hline Season of Calving & NS & ** & ** & NS & \\
\hline \multirow[t]{2}{*}{1 (Winter) } & $1.5 \pm 4$ & $267.33 \pm 22.1$ & $201.22 \pm 29.62$ & $79.66 \pm 3.54$ & \multirow[t]{2}{*}{66.67} \\
\hline & (6) & (6) & (9) & (12) & \\
\hline \multirow[t]{2}{*}{ 2(Spring) } & $1.5 \pm 0.5$ & $187.00 \pm 81$ & $229.67 \pm 71.89$ & 98.28 & \multirow[t]{2}{*}{66.67} \\
\hline & (2) & (2) & (3) & (1) & \\
\hline \multirow[t]{2}{*}{ 3(Summer) } & $1.75 \pm 0.25$ & $180.75 \pm 9.82$ & $149.00 \pm 10.4$ & 71.55 & \multirow[t]{2}{*}{80.00} \\
\hline & (4) & (4) & (5) & (1) & \\
\hline \multirow[t]{2}{*}{ 4(Rainy) } & $1.5 \pm 0.22$ & $107.56 \pm 9.86$ & $101.6 \pm 8.76$ & $85.66 \pm 2.66$ & \multirow[t]{2}{*}{80.00} \\
\hline & (16) & (16) & (20) & (15) & \\
\hline \multirow[t]{2}{*}{ 5(Autumn) } & $1.2 \pm 0.2$ & $77.4 \pm 5.29$ & $86.38 \pm 5.89$ & $86.6 \pm 3.24$ & \multirow[t]{2}{*}{31.25} \\
\hline & (5) & (5) & (16) & (18) & \\
\hline $\begin{array}{l}\text { Body weight at } \\
\text { current calving }\end{array}$ & NS & * & NS & NS & \\
\hline \multirow[t]{2}{*}{$1(\leq 550 \mathrm{~kg})$} & 1.0 & $93.0 \pm 2.0$ & $81.67 \pm 11.39$ & $75.97 \pm 2.25$ & \multirow[t]{2}{*}{66.67} \\
\hline & (2) & (2) & (3) & (3) & \\
\hline \multirow[t]{2}{*}{ 2(551-650kg) } & $1.25 \pm 0.13$ & $137.42 \pm 22.48$ & $131.23 \pm 16.45$ & $88.45 \pm 2.59$ & \multirow[t]{2}{*}{54.55} \\
\hline & (12) & (12) & (22) & (17) & \\
\hline \multirow[t]{2}{*}{$3(651-750 \mathrm{~kg})$} & $1.62 \pm 0.22$ & $148.81 \pm 21.45$ & $120.39 \pm 14.72$ & $81.62 \pm 2.72$ & \multirow[t]{2}{*}{69.57} \\
\hline & (16) & (16) & (23) & (23) & \\
\hline \multirow[t]{2}{*}{$4(>750 \mathrm{~kg})$} & $2.0 \pm 0.11$ & $197.67 \pm 27.97$ & $151.6 \pm 23.18$ & $90.13 \pm 7.69$ & \multirow[t]{2}{*}{60.00} \\
\hline & (3) & (3) & (5) & (4) & \\
\hline \multirow[t]{2}{*}{ Overall mean } & $1.63 \pm 0.19$ & $139.89 \pm 18.08$ & $112.36 \pm 9.78$ & $84.46 \pm 1.81$ & \multirow{5}{*}{40.00} \\
\hline & (19) & (19) & (36) & (47) & \\
\hline Dry period & NS & NS & NS & $* *$ & \\
\hline \multirow[t]{2}{*}{1 (_90days) } & $1.5 \pm 0.5$ & $124.33 \pm 36.32$ & $105.2 \pm 22.6$ & $96.56 \pm 2.58$ & \\
\hline & (2) & (2) & (5) & (6) & \\
\hline \multirow[t]{2}{*}{ 2(91-120days) } & $1.88 \pm 0.35$ & $140.75 \pm 27.57$ & $113.91 \pm 18.66$ & $93.92 \pm 1.07$ & \multirow[t]{2}{*}{72.73} \\
\hline & (8) & (8) & (11) & (12) & \\
\hline \multirow[t]{2}{*}{ 3(121-150days) } & $1.33 \pm 0.21$ & $128 \pm 23.65$ & $100.56 \pm 16.48$ & $82.63 \pm 1.85$ & \multirow[t]{2}{*}{66.67} \\
\hline & (6) & (6) & (9) & (13) & \\
\hline \multirow[t]{2}{*}{ 4(>150days) } & $1.67 \pm 0.67$ & $195.5 \pm 135.5$ & $123.73 \pm 21.19$ & $74.3 \pm 3.27$ & \multirow[t]{2}{*}{27.27} \\
\hline & (3) & (3) & (11) & (16) & \\
\hline
\end{tabular}

$* *: \mathrm{P} \leq 0.01 ; *: \mathrm{P} \leq 0.05$ and NS: Non-significant

Figures given in the parenthesis indicate number of animals

NoS/C- No. of services per conception, SP-post partum service period, PPIE: Post partum interval to estrus, BE:

Breeding efficiency, CR: Conception rate

\section{Effect of season of calving}

The effect of season of calving on reproductive traits revealed a highly significant $(\mathrm{P} \leq 0.01)$ influence on service period and PPIE, where in it may be seen that ideal shorter SP (77.4 \pm 5.29 days) and PPIE (86.38 \pm 5.89 days) was in autumn calved buffaloes and highest in winter calved. It was studied that only five buffaloes conceived lout 
of 16 autumn calved buffaloes that showed first sign of heat and NoS/C was also lower in the same class though the effect was nonsignificant. Whereas, 20 buffaloes that calved during the rains exhibited heat in 101.6 days and 16 conceived with a mean of 107.56 days of service period. Hence better conception rat was achieved in buffaloes that calved during rainy season. Climate after the rains was conducive and there was abundant availability of good quality fodders. Jamuna et al., (2015) reported significant effect on SP and days to first service and also observed longer service period in winter calved buffaloes followed by summer and autumn calved and findings were similar to the present study. On the contrary, Ramadan et al., (2018) observed better reproductive performance in winter calved Egyptian buffaloes.

\section{Effect of body weight at calving}

Body weight at calving influenced service period significantly $(\mathrm{P}<0.05)$ and it was clear that lighter the animal shorter were the interval to estrus and service period. While non-significant differences were found among other reproductive parameters. However the buffaloes belonging to $\leq 550 \mathrm{~kg}$ body weight had a comparatively better reproductive performance. Roche et al., (2007) reported that body weight change at calving had significant effect on reproductive traits of dairy cattle.

\section{Effect of dry period}

Breeding efficiency of buffaloes was significantly influenced by the dry period days and the other parameters also showed non-significant variation. Generally dry period is considered to be very important trait for the animal to recoup its condition during peripartum period. It was observed that as the dry period was shortened the buffaloes exhibited better reproductive parameters.
Grummer et al., (2007) has published a report that states shortening the dry period would improve the reproductive efficiency in dairy animals. While, Van Knegsel et al., (2013) has reported that omission or shortening of the dry period did not change the fertility parameters during the next lactation.

In conclusion, the age at calving, season of calving, Body weight at calving and dry period had significantly influenced the reproductive parameters like service period, post partum interval to estrus and breeding efficiency while, did not show any effect on number of services per conception. Hence age, season and body weight at calving could be considered as indicative parameters and used as a tool to modify the management while planning for the improvement of reproductive traits. These traits indicate the health and efficiency of dairy animals. Similarly changes in BCS at calving may be considered while modifying feeding and breeding strategies for better performance in buffaloes.

\section{Disclosure statement}

No potential conflict of interest was reported by the authors.

\section{References}

Basic Animal Husbandry Statistics (BAHS). 2019. Department of Animal Husbandry, Dairy and Fisheries, Government of India. http://dahd.nic.in/Division/statistics/animalhusbandry.../basichusbandry-statistics-2019.

Bayram B, Aksakal V, Akbulut O. 2012. Effect of the body condition score on some reproduction and milk yield traits of Swedish red and white cows. J ANIM PLANT SCI. 22 (3):545-551.

Boopathi V, Prasad S, Kumaresan A, Manimaran A, Prakash MA. (2019). Environmental factors affecting reproductive performance of Murrah buffaloes. BIOL RHYTHM RES. 1-7. 
Ghavi Hzn, Akbarian M. 2015. Factors Affecting Body Condition Score and Its Relationship with Productive and Reproductive Performances of Holstein Cows Iran. J. Appl. Anim. Sci.5(1):73-79.

Godara AS, Tomar AKS, Dutt T, Patel BHM, Kumari A, Singh M, Verma MR. 2016. Effect of Post-Partum Body Condition Score on Productive, Reproductive and Calf Birth Weight Performance in Tharparkar Cattle. Int J Livest Res. 7(4):166-171.

Grummer RR. 2007. Strategies to improve fertility of high yielding dairy farms: management of the dry period. Theriogenology. 68:S281S288.

Ingawale MV, Dhoble RL. 2004. Buffalo reproduction in India: an overview. Buffalo Bull. 23(1):4-9.

Jamuna V, Chakravarty AK, Patil CS. 2015. Influence of non-genetic factors on performance traits in Murrah buffaloes. Indian J Anim Res. 49(3):279-283.

Jílek F, Pytloun $P$, Kubešová $M$, Štípková $M$, Bouška J, Volek J, Rajmon R. 2008. Relationships among body condition score, milk yield and reproduction in Czech Fleckvieh cows. Czech J Anim Sci. 53(9):357-367.

Kumar K, Nanavati S, Joshi SK, Choudhary NS. 2018. Studies on body condition score and its relationship with service period in frieswal cows. Theriogenology Insight-An International Journal of Reproduction in all Animals. 8(2):69-71.

Messine Ombionyo, Schwalbach LJM, Mbah Diane, Ebangi AL. 2007. Non-genetic Factors Affecting Gestation Lenght and Postpartum Intervals in Gudali Zebu Cattle of the Adamawa Highlands of Cameroon. Tropicultura. 25.

Mouffok C, Madani T, Smara L, Baitiche M, Allouche L, Belkasmi F. 2011. Relationship between body condition score, body weight, some nutritional metabolites changes in blood and reproduction in Algerian Montbeliad cows. Vet World. 4(10).

Patil CS, Chakravarty AK, Kumar V, Dongre VB, Kumar P. 2012. Non-genetic factors affecting first lactation reproductive traits in Murrah buffaloes. Indian J Anim Res. 46(2):205-207.

Patil CS, Chakravarty AK, Kumar V, Dongre VB, Kumar P. 2012. Non-genetic factors affecting first lactation reproductive traits in Murrah buffaloes. Indian J Anim Res. 46(2):205-207.

Ramadan SI. 2018. Effect of some genetic and non-genetic factors on productive and reproductive traits of Egyptian buffaloes. J Adv Vet Anim Res. 5(4):374.

Roche JR, Macdonald KA, Burke CR, Lee JM, Berry DP. 2007. Associations among body condition score, body weight, and reproductive performance in seasonalcalving dairy cattle. J DAIRY SCI. 90(1):376-391.

Sastry NSR. 2003. Proc. 4th Asian Buffalo Congress 25-28th Feb. 2003. New Delhi. $1: 169-171$.

Stefańska B, Poźniak A, Nowak W. 2016. Relationship between the pre-and postpartum body condition scores and periparturient indices and fertility in highyielding dairy cows. J VET RES. 60(1):8190.

Tiwari R, Sharma M, Singh B. 2007. Buffalo calf health care in commercial dairy farms: a field study in Uttar Pradesh (India). Livest. Res. Rural. Dev.. 19(3):8.

Van Knegsel AT, Van der Drift SG, Čermáková J, Kemp B. 2013. Effects of shortening the dry period of dairy cows on milk production, energy balance, health, and fertility: A systematic review. Vet J. 198(3):707-713.

\section{How to cite this article:}

Cherryl D. Miranda, A. K. S. Tomar, Gyanendra Singh, Hari Om Pandey, Pratik R. Wankhede and Arun Somagond. 2020. Ante-partum Body Condition Score and Non-genetic Factors Influencing the Post-partum Fertility in Murrah Buffaloes. Int.J.Curr.Microbiol.App.Sci. 9(11): 1152-1158. doi: https://doi.org/10.20546/ijcmas.2020.911.134 